\title{
Pendidikan Agama Islam sebagai Basis Penguatan Sikap Patriotisme
}

\author{
Moh. Fatkur Rohman, ${ }^{1}$ Tasman Hamami ${ }^{2}$ \\ ${ }^{1,2}$ Universitas Islam Negeri Sunan Kalijaga Yogyakarta, Indonesia \\ ${ }^{1}$ rahmanonlyme@ashshohibiyah.sch.id, ${ }^{2}$ tasmanhamami61@gmail.com
}

\begin{abstract}
The very rapid development of science and technology, as well as the ease of access to information, can have a negative impact on people's attitudes and behavior, including the phenomenon of the diminishing patriotism of the younger generation. Patriotism is the foundation of citizen life and the foundation of national and state life. This study examines Islamic Religious Education as a basis for strengthening students' patriotism attitudes. This study aims to describe and demonstrate the role of Islamic Religious Education in strengthening students' patriotism attitudes. This study was conducted at SMA Kemala Bhayangkari 1 Surabaya using a qualitative approach. Data collection was carried out through observation and in-depth interviews. The results showed that Islamic Religious Education contains teachings and values that strengthen students' patriotism. Strategies for strengthening patriotism in Islamic Religious Education through advice, exemplary and habituation in everyday life at school. This Islamic Religious Education Model is an alternative solution to arouse students' patriotism.
\end{abstract}

Keywords: Model, Patriotism, Islamic Religious Education, Students, Strengthening.

\begin{abstract}
Abstrak
Perkembangan ilmu pengetahuan dan teknologi yang sangat pesat, serta kemudahan untuk mengakses informasi dapat berdampak negatif terhadap sikap dan perilaku masyarakat, termasuk fenomena lunturnya sikap patriotisme generasi muda. Sikap patriotisme merupakan sendi kehidupan warga negara dan sebagai fondasi kehidupan berbangsa dan bernegara. Penelitian ini mengkaji Pendidikan Agama Islam sebagai basis penguatan sikap patriotisme siswa. Penelitian ini bertujuan untuk mendeskripsikan dan menunjukkan peran Pendidikan Agama Islam dalam penguatan sikap patriotisme siswa. Studi ini dilakukan di SMA Kemala Bhayangkari 1 Surabaya dengan menggunakan pendekatan kualitatif. Pengumpulan data dilakukan melalui observasi dan wawancara mendalam. Hasil penelitian menunjukkan bahwa Pendidikan Agama Islam memuat ajaran dan nilai-nilai yang menguatkan sikap patriotisme siswa. Strategi penguatan sikap patriotisme dalam Pendidikan Agama Islam melalui nasehat, keteladanan dan pembiasaan dalam kehidupan sehari-hari di sekolah. Model Pendidikan Agama Islam ini menjadi solusi alternatif untuk membangkitkan sikap patriotisme siswa.
\end{abstract}

Kata Kunci: Model, Patriotisme, Penguatan, Pendidikan Agama Islam, Siswa.

\section{Pendahuluan}

Dalam kehidupan berbangsa dan bernegara, patriotisme atau cinta tanah air sikap yang sangat penting dan wajib dimiliki oleh setiap warga negara. Patriotisme merupakan salah satu karakter bangsa yang dipupuk dan dikembangkan untuk menjaga identitas dan keutuhan bangsa. Setiap warga dari suatu bangsa, termasuk bangsa Indonesia memiliki kewajiban untuk mencintai tanah air dan budaya bangsanya sendiri. Istilah "patriotisme" 
berasal dari kata "patriot" berarti sifat kepahlawanan atau jiwa pahlawan. Patriotisme berkaitan dengan sikap berani, pantang menyerah dan rela berkorban untuk bangsanya. Karena itu, patriotisme merupakan sikap yang bersumber dari perasaan cinta pada tanah air sehingga menimbulkan kerelaan berkorban untuk bangsa dan negaranya. ${ }^{1}$ Dalam konteks kehidupan berbangsa dan bernegara, sikap patriotisme ditandai dengan sikap positif lainnya, yaitu: cinta tanah air rela berkorban untuk kepentingan bangsa dan negara menempatkan persatuan, kesatuan serta keselamatan bangsa dan negara diatas kepentingan pribadi dan golongan berjiwa pembaharu tidak kenal menyerah. ${ }^{2}$

Patriotisme sebagai salah satu bentuk karakter tidak terbentuk dengan sendirinya, melainnkan memerlukan proses pendidikan dan pembudayaan. Penanaman dan pengembangan sikap patriotisme merupakan salah satu misi yang menjadi perhatian Sekolah Menengah Atas (SMA) Kemala Bhayangkari 1 Surabaya. Sekolah ini merupakan lembaga pendidikan swasta yang berada di bawah naungan Yayasan Ibu Bhayangkari Polda Jawa Timur. Sekolah yang berada dalam "budaya kepolisian” ini sejak awal berdirinya memiliki ciri khusus pada penanaman kedisiplinan baik di kalangan guru, tenaga kependidikan maupun siswa. Keunikan lain dari sekolah ini juga terdapat dalam pencitraan budaya sekolah yang kondusif, dan perhatiannya yang besar terhadap pembentukan karakter kebangsaan, nasionalisme dan patriotisme. Patriotisme merupakan karakter yang sangat penting dalam kehidupan bangsa dan negara sebagai benteng keamanan dan keutuhan bangsa Indonesia terhadap lahirnya ideologi-ideologi asing yang tidak selaras dengan jati diri bangsa. ${ }^{3}$ Akibatnya, apabila tidak ada penekanan dan kesadaran untuk bela negara, maka sikap patriotisme lambat laun juga akan mengalami penurunan. Penanaman sikap patriotisme dilakukan melalui budaya sekolah maupun internalisasi nilai-nilai ajaran Islam dalam mata pelajaran Pendidikan Agama Islam (PAI).

Perhatian SMA Kemala Bhayangkari Surabaya terhadap pembentukan sikap patriotisme, dapat dilihat dari berbagai terobosan yang dilakukan antara lain melalui Pendidikan Agama Islam yang mengintegrasikan pendidikan karakter kebangsaan. Pendidikan Agama Islam sebagai salah satu wadah untuk mengajarkan dan membina

\footnotetext{
${ }^{1}$ Sarjit S Gill Profesor et al., "Kesedaran Patriotik Dalam Kalangan Belia Bandar Di Semenanjung Malaysia Mohd Rahimi Ramli,” Jurnal Sosial Ilmu Politik Universitas Hasanuddin, 2015.

${ }^{2}$ Rahmat Wijayanto J. and Marzuki Marzuki, "Pendidikan Bela Negara Sebagai Tonggak Peradaban Jiwa Patriotisme Generasi Muda," Jurnal Ilmiah Pendidikan Pancasila Dan Kewarganegaraan 3, no. 2 (December 26, 2018): 186, https://doi.org/10.17977/um019v3i2p186-191.

${ }^{3}$ Wijayanto J. and Marzuki. 
karakter, memuat materi yang dianggap mampu berintegrasi dengan kebutuhan negara dan bangsa. Dengan demikian, PAI dalam penerapannya, di samping menekankan pembelajaran yang bersifat teologis dan religius, juga harus dapat berintegrasi dengan ilmu pengetahuan umum, salah satunya adalah terkait tentang pendidikan kewarganegaraan dan kebangsaan. Secara tersirat, kurikulum Pendidikan Agama Islam memuat materi yang berkaitan dengan kehidupan bernegara. Penyampaian nilai-nilai kebangsaan dan kenegaraan dalam pembelajaran PAI membutuhkan penekanan dan penguatan yang lebih komprehensif.

Seiring perkembangan ilmu pengetahuan dan teknologi yang semakin pesat, informasi-informasi dari berbagai negara di belahan dunia dapat diakses dengan mudah. Akses informasi yang semakin mudah dan cepat, ternyata berdampak luas terhadap kehidupan manusia, baik dampak positif maupun negatife. ${ }^{4}$ Dampak positif kemajuan teknologi informasi adalah memudahkan dan mempercepat akses masyarakat terhadap berbagai kebutuhan, namun teknologi informasi juga dapat berdampak pada pergeseran kebudayaan masyarakat. ${ }^{5}$ Banyak penelitian yang menunjukkan adanya pengaruh budaya asing terhadap kebudayaan masyarakat Indonesia, terutama di kalangan kaum muda, misalnya budaya budaya pop atau Kpop Korea banyak digemari dan melanda Indonesia. ${ }^{6}$ Berbagai pengaruih budaya asing telah mempengaruhi gaya hidup (lifestyle) masyarakat Indonesia, khususnya generasi muda ${ }^{7}$. Fenomena ini berpotensi menjadi penyebab rentannya sikap patriotisme masyarakat dan bangsa Indonesia, terutama kalangan generasi muda. Berbagai kasus perilaku korupsi, penggunaan Narkoba, dan tawuran siswa yang terjadi Indonesia merupakan indikasi rapuhnya karakter bangsa. ${ }^{8}$ Krisis karakter ini berpotensi melemahkan sikap patriotisme.

${ }^{4}$ Robby Darwis Nasution, "Pengaruh Modernisasi Dan Globalisasi Terhadap Perubahan Sosial Budaya Di Indonesia,” Jurnal Kominfo, 2017.

5 Daryanto Setiawan, "Dampak Perkembangan Teknologi Informasi Dan Komunikasi Terhadap Budaya," JURNAL SIMBOLIKA: Research and Learning in Communication Study, 2018, https://doi.org/10.31289/simbollika.v4i1.1474.

${ }^{6}$ Hamdani M. Syam, "Globalisasi Media Dan Penyerapan Budaya Asing, Analisis Pada Pengaruh Budaya Populerkorea Di Kalangan Remaja Kota Banda Aceh," Avant Garde, 2015, https://doi.org/10.36080/AVG.V3I1.19.

7 Sigit Vebrianto Susilo, "Refleksi Nilai-Nilai Pendidikan Ki Hadjar Dewantara Dalam Upaya Upaya Mengembalikan Jati Diri Pendidikan Indonesia," Jurnal Cakrawala Pendas, 2018, https://doi.org/10.31949/jcp.v4i1.710.

${ }^{8}$ Arif Rahman Prasetyo, "Implementasi Kebijakan Pendidikan Karakter Di Madrasah Tsanawiyah Muhammadiyah Al Manar Kabupaten Demak," Tribakti: Jurnal Pemikiran Keislaman, 2020, https://doi.org/10.33367/tribakti.v31i1.978.

Tribakti: Jurnal Pemikiran Keislaman Volume 32, Nomor 1, Januari 2021 
Merebaknya kasus korupsi di Indonesia yang dilakukan oleh pejabat negara merupakan indikasi adanya krisis karakter. ${ }^{9}$ Sekalipun berbagai perangkat pemberantasan korupsi di Indonesia, baik regulasi, lembaga dan aparat penegakan hukum telah disiapkan, namun tingginya angka korupsi yang dilakukan oleh pejabat-pejabat negara. Berdasarkan data kasus penindakan terhadap korupsi sejak tahun 2016 hingga 2018 mengalami peningkatan jumlah kasus yang signifikan. ${ }^{10}$ Tingginya angka korupsi di Indonesia yang dilakukan oleh oknum penyelenggara negara menunjukkan bahwa mereka kurang memiliki sikap patriotisme. Secara normatif, mereka adalah pemimpin yang menjadi panutan rakyat, tetapi mereka justru bersikap dan berperilaku negatif. Tugas pemimpin adalah menyejahterakan rakyat yang dipimpinnya, bukan sebaliknya, menggunakan uang negara untuk kepentingan pribadinya. Korupsi adalah manifestasi dari egoisme individu yang bertentangan dengan norma hukum, masyarakat, bahkan agama karena menimbulkan kerusakan yang sangat fatal. Korupsi merupakan perbuatan tindak pidana yang melanggar hak-hak sosial dan hak-hak ekonomi masyarakat, sehingga tindak pidana korupsi tidak lagi dapat digolongkan sebagai kejahatan biasa (ordinary crimes) melainkan telah menjadi kejahatan luar biasa (extra ordinary crimes). ${ }^{11}$

Fenomena memudarnya karakter di Indonesia juga nampak pada maraknya penyalahgunaan narkoba, dan tawuran antar siswa. Banyak penelitian mengungkapkan bahwa penggunaan narkoba di Indonesia sudah sampai pada kondisi yang mengkhawatirkan. ${ }^{12}$ Jumlah pengguna narkoba sudah demikian masif dan menimpa semua kalangan. Badan Narkotika Nasional (BNN) menyatakan bahwa Indonesia darurat narkoba. ${ }^{13}$ Penggunaan narkoba itu tidak hanya di kota, tetapi narkoba telah masuk desa. ${ }^{14}$ Banyak alasan yang menyebabkan seseorang terjerumus dalam penggunaan narkoba, di

${ }^{9}$ Ainun Muchlisatun Rati Sugiman, "Penanaman Nilai-Nilai Nasionalisme Dan Patriotisme Melalui Materi Sikap Semangat Kebangsaan Dan Patriotisme Dalam Kehidupan Bermasyarakat, Berbangsa Dan Bernegara Pada Pembelajaran Pkn Di Sman 1 Pundong," Academy of Education Journal 8, no. 2 (July 1, 2017): 174-99, https://doi.org/10.47200/aoej.v8i2.370.

10 Suherry Suherry, "Politik Pemberantasan Korupsi Di Indonesia," Otoritas : Jurnal Ilmu Pemerintahan, 2017, https://doi.org/10.26618/ojip.v7i1.417.

${ }^{11}$ Ifrani Ifrani, "Tindak Pidana Korupsi Sebagai Kejahatan Luar Biasa," Al Adl : Jurnal Hukum, 2017.

12 Maudy Pritha Amanda, Sahadi Humaedi, And Meilanny Budiarti Santoso, "Penyalahgunaan Narkoba Di Kalangan Remaja (Adolescent Substance Abuse)," Prosiding Penelitian Dan Pengabdian Kepada Masyarakat, 2017, Https://Doi.Org/10.24198/Jppm.V4i2.14392.

${ }^{13}$ Badan Narkotika Nasional Republik Indonesia, "Indonesia Drugs Report 2019," Pusat Penelitian Dan Informasi Badan Narkotika Nasional Republik Indonesia (Puslidatin BNN), 2019.

14 Iwan Setyawan and Sri Sulistyawati, "Mewaspadai Bahaya Penyalahgunaan Narkotika Pada Kalangan Masyarakat Desa Bandar Khalifah Kecamatan Percut Sei Tuan Kabupaten Deli Serdang," in Prosiding Seminar Nasional Hasil Pengabdian 2019, 2019. 
antaranya adalah faktor kepribadian, keluarga, ekonomi, pergaulan, dan sosial. Krisis karakter, khususnya di kalangan remaja ditandai dengan maraknya tawuran antar pelajar. ${ }^{15}$ Banyak faktor yang dapat memicu terjadinya tawuran antar pelajar, seperti faktor tabiat, keluarga, pergaulan, perlakuan kekerasan, ${ }^{16}$ solidaritas kelompok, ${ }^{17}$ dan rendahnya kecerdasan emosional. ${ }^{18}$ Berbagai krisis karater tersebut berpotensi menjadi penyebab rendahnya sikap patriotisme, terutama di kalangan remaja.

Membangun sikap patriotisme sangat sangat penting dalam kehidupan berbangsa dan bernegara, karena rendahnya patriotisme mengancam keutuhan, bahkan bangsa Indonesia. Hal itu terjadi karena seiring rendahnya sikap patriotisme, ketahanan nasional juga akan lemah, sehingga rentan terhadap intervensi pihak luar. Oleh sebab itu, upaya menguatkan kembali sikap patriotisme sangat strategis dalam menjaga kedaulatan negara. Penguatan sikap patriotisme dapat difokuskan pada penanaman dan pembudayaan indikator patriotisme, yaitu: cinta tanah air, rela berkorban untuk kepentingan bangsa dan negara, menempatkan persatuan dan kesatuan bangsa diatas kepentingan pribadi dan golongan, berjiwa pembaharu, serta tidak kenal menyerah dan putus asa. ${ }^{19}$ Beberapa penelitian menunjukkan strategi penguatan sikap patriotisme.

Rahmat Wijayanto dan Marzuki menunjukkan penguatan sikap patriotisme melalui pendidikan bela negara. ${ }^{20}$ Pendidikan bela negara berkontribusi positif terhadap pembentukan semangat patriotik siswa sejak dini. Penelitian Subaryana menekankan pada pembentukan konsep diri yang positif sebagai cara untuk membangun sikap patriotisme yang konstruktif. ${ }^{21}$ Sejalan dengan penelitian ini, Mursidin ${ }^{22}$ dalam penelitiannya menyimpulkan Pendidikan Agama Islam berbasis nasionalisme melalui

15 A. Said Hasan Basri, "Fenomena Tawuran Antar Pelajar Dan Intervensinya," Hisbah: Jurnal Bimbingan Konseling Dan Dakwah Islam, 2016, https://doi.org/10.14421/hisbah.2015.121-06.

${ }^{16}$ Heni Hayat, "Komunikasi Kekerasan Penyebab Tindak Kekerasan Dalam Tawuran," Journal Acta Diurna, 2019, https://doi.org/10.20884/1.actadiurna.2019.15.1.1579.

17 elly malihah, bunyamin maftuh, and rizki amalia, "tawuran pelajar: solidarity in the student group and its influence on brawl behaviour," Komunitas: International Journal of Indonesian Society And Culture, 2015, https://doi.org/10.15294/komunitas.v6i2.3301.

18 Nuri Aprilia and Herdina Indrijati, "Hubungan Antara Kecerdasan Emosi Dengan Perilaku Tawuran Pada Remaja Laki-Laki Yang Pernah Terlibat Tawuran Di SMK 'B' Jakarta,' Jurnal Psikologi Pendidikan Dan Perkembangan, 2014.

${ }^{19}$ Y S Putra, "Perkembangan Jiwa Nasionalisasi Dan Patriotisme Era Reformasi Di Indonesia," Jurnal Dosen Universitas PGRI. 2017.

20 Wijayanto J. and Marzuki, "Pendidikan Bela Negara Sebagai Tonggak Peradaban Jiwa Patriotisme Generasi Muda."

${ }^{21}$ Subaryana, "Builing the Positive Self-Concept through Patriotism," Jurnal Dinamika Pendidikan Dasar, 2016.

22 Mursidin Mursidin, "Pendidikan Agama Islam Berbasis Nasionalisme," Ta'dib: Jurnal Pendidikan Islam, 2019, https://doi.org/10.29313/tjpi.v8i1.4515.

Tribakti: Jurnal Pemikiran Keislaman

Volume 32, Nomor 1, Januari 2021 
kehidupan keagamaan (intra dan antar umat beragama) yang interaktif, dialogis dan toleran sehingga menumbuhkan semangat kebersamaan dan kerjasama. Penelitian ini memperjelas hubungan antara agama Islam dengan sikap patriotisme, bahwa Islam mengajarkan sikap patriotisme. ${ }^{23}$ Relasi antara ajaran Islam dengan sikap patriotisme dalam konteks Indonesia bukan hal yang baru, karena telah ditunjukkan oleh sikap patriotisme para tokoh Islam pendiri bangsa Indonesia.

Prinsip-prinsip relasi antara agama Islam dengan faham kebangsaan banyak tersirat dalam ayat Alqur'an. Azman dalam kajiannya tentang "Nasionalisme dalam Islam" menunjukkan ayat-ayat Al-qur'an sebagai sumber. Dia menyimpulkan bahwa semangat nasionalisme yang berdasarkan atas persamaan niat dan tujuan untuk bersatu dan membangun bangsa menuju masa depan yang lebih baik terinspirasi dengan ayat Alqur'an Allah menciptakan manusia bersuku-suku dan berbangsa-bangsa bertujuan untuk saling kenal mengenal sehingga tercipta kebersamaan dan keharmonisan dalam kehidupan berbangsa dan bermasyarakat. ${ }^{24}$ Penelitian lain juga menunjukkan Pendidikan Agama Islam sebagai mata pelajaran memuat materi-materi yang berisi ajaran Islam yang sejalan dengan nilai-nilai kebangsaan. Islam adalah agama yang mengajarkan bagi pemeluknya untuk mencintai negaranya dengan sepenuh hati. Dalam penelitian dua tokoh Islam yang nasionalis, Iwan Setiawan mengkritik faham dikotonomis antara Islam dan nasionalis di Indonesia. ${ }^{25}$ Konsep penggabungan antara ajaran agama dan nilai-nilai kebangsaan, khususnya sikap patriotisme menjadi hal yang sangat penting untuk diimplementasikan dalam pendidikan untuk membentuk dan menguatkan sikap patriotisme siswa. Pandangan integrasi antara Islam dan penguatan sikap patriotisme merupakan pola pendidikan yang memberi arah dan konsep baru bagi Pendidikan Agama Islam.

Berbagai penelitian terdahulu menunjukkan adanya relasi yang searah antara ajaran agama Islam dengan sikap patriotisme. Seperti halnya Abdul Hamid dalam jurnalnya menerangkan bahwa penyebab konflik komunal yang terjadi di Indonesia bukan disebabkan oleh Agama Islam. Menurutnya, secara konseptual Islam sejalan

${ }^{23}$ Nasihun Amin, "Menyemai Nasionalisme Dari Spirit Agama: Upaya Meredam Radikalisme Beragama," Jurnal Theologia, 2012.

24 Azman Azman, "Nasionalisme Dalam Islam," Al Daulah : Jurnal Hukum Pidana Dan Ketatanegaraan, 2017, https://doi.org/10.24252/ad.v6i2.4881.

25 Iwan Setiawan, "Islam Dan Nasionalisme: Pandangan Pembaru Pendidikan Islam Tentang Nasionalisme (Kasus Ahmad Dahlan Dan Abdul Wahab Khasbullah)," Equilibrium: Jurnal Pendidikan, 2018, https://doi.org/10.26618/equilibrium.v5i2.1046. 
dengan nilai-nilai kebangsaan. ${ }^{26}$ Oleh sebab itu, penelitian ini secara lebih spesifik fokus pada bagaimana peran Pendidikan Agama Islam sebagai basis penguatan sikap patriotisme di SMA Kemala Bhayangkari Surabaya yang peduli dengan pendidikan kebangsaan. Fenomena penguatan sikap patriotisme berbasis PAI di SMA Kemala Bhayangkari Surabaya menarik dan sangat penting untuk dikaji sebagai salah satu model penguatan sikap patriotisme. SMA Kemala Bhayangkari berhaluan nasionalis, namun memberikan perhatian besar terhadap PAI sebagai basis pembentukan sikap patriotisme didasarkan pada pandangan bahwa Islam kaya dengan ajaran dan nilai-nilai patriotisme. Hasil penelitian ini memberikan perspektif baru tentang peran PAI yang tidak hanya berkaitan dengan pendidikan agama Islam dalam aspek akidah dan ibadah, tetapi juga menjadi landasan pendidikan karakter kebangsaan.

\section{Metode}

Penelitian ini menggunakan pendekatan kualitatif dengan metode analisis deskriptif. Jenis penelitian empiris fokus pada penguatan sikap patriotisme siswa berbasis Pendidikan Agama Islam di SMA Kemala Bhayangkari 1 Surabaya. Metode pengumpulan data menggunakan wawancara, observasi dan dokumentasi. ${ }^{27}$ Wawancara mendalam untuk memperoleh data secara menyeluruh dari narasumber sebanyak 10 orang, terdiri dari 3 (tiga) orang guru PAI dan 6 (enam) orang siswa, serta 1 (satu) orang staf yang ditentukan dengan cara purposive. Penentuan narasumber didasarkan pada observasi awal yang telah dilakukan oleh peneliti. Dalam proses wawancara, masingmasing narasumber diwawancarai secara terpisah dengan pertanyaan secara mendalam. Fokus wawancara mengenai penguatan sikap patriotisme berbasis Pendidikan Agama Islam. Selanjutnya, untuk memperoleh data terkait sikap patriotisme peserta didik, peneliti menggunakan teknik observasi. Pelaksanaan observasi bekerja sama dengan guru PAI, dan melakukan kegiatan visiting ke kelas untuk mengamati secara langsung terhadap sikap dan perilaku perilaku siswa yang mencerminkan sikap patriotisme. Observasi juga dilakukan untuk memperoleh data, bagaimana pembelajaran PAI mengkorelasikan dengan penguatan sikap patriotisme. Pengumpulan data juga menggunakan dokumentasi untuk memperoleh data tentang portofolio yang menginformasikan sikap patriotisme siswa.

\footnotetext{
${ }^{26}$ Abdul Hamid. Peranan Pendidikan Agama Islam Dalam Penguatan Nasionalisme Di Indonesia. Jurnal Pendidikan Agama Islam. 2018. https://doi.org/10.14421/jpai.2018.151-02

${ }^{27}$ Louis Cohen, Lawrence Manion, and Keith Morrison, Research Methods in Education, Research Methods in Education, 2017, https://doi.org/10.4324/9781315456539.

Tribakti: Jurnal Pemikiran Keislaman

Volume 32, Nomor 1, Januari 2021
} 
Analisis data penelitian ini menggunakan model analisis interaktif dari Miles, Huberman, \& Saldana. Model analisis interaktif ini memiliki tiga komponen, yaitu: (1) kondensasi data, (2) penyajian data, dan (3) penarikan kesimpulan/verifikasi. ${ }^{28}$ Pada tahap kondensasi data, peneliti memilih, memfokuskan, menyederhanakan, mengabstraksikan, dan mentransformasikan data yang berasal dari catatan lapangan tertulis, catatan wawancara, maupun dokumen. Tahap kedua dari aktivitas analisis adalah menyajikan data yang mencakup sekumpulan informasi yang memberi kemungkinan kepada peneliti untuk menarik simpulan dan mengambil tindakan. Sajian data ini merupakan susunan organisasi informasi dalam bentuk deskripsi dan narasi yang lengkap, yang disusun berdasarkan pokok-pokok temuan yang terdapat dalam reduksi data. Tahap yang terakhir analisis data adalah penarikan simpulan yang merupakan penafsiran terhadap hasil analisis dan interpretasi data serta pembahasan.

\section{Hasil dan Pembahasan}

Indikasi menurunnya sikap patriotisme di kalangan masyarakat, khususnya generasi muda merupakan masalah bangsa yang krusial. Beberapa tahun belakangan, berbagai macam krisis sikap patriotisme terjadi di tengah-tengah masyarakat, sehingga bangsa dan negara Indonesia menghadapi ancaman penetrasi budaya asing yang bersifat negartif terhadap budaya luhur bangsa Indonesia. Salah satu contohnya adalah masuknya budaya bangsa lain yang diikuti oleh masyarakat Indonesia, serta gaya hidup yang semakin global. Penelitian ini menggambarkan sikap patriotisme siswa SMA Kemala Bhayangkari 1 Surabaya, dan mengungkapkan implementasi penguatan sikap patriotisme berbasis Pendidikan Agama Islam.

Fenomena krisis sikap patriotisme, terutama generasi muda cukup dirasakan oleh siswa. Informan Z1 menggambarkan bagaimana sikap generasi muda yang cenderung lebih menyukai budaya asing dari pada budaya sendiri, seperti menonton K-Pop, dan mainan Tik Tok. Banyak juga anak-anak muda yang lebih bangga dengan bahasa asing dari pada Bahasa Indonesia. Dia menuturkan "banyak generasi muda, termasuk anakanak yang cenderung lebih suka pada budaya asing dari pada budaya sendiri." Pada sisi lain, sikap patriotisme juga dapat tergerus dengan faham-faham ideologi apapun yang tidak sejalan dengan prinsip-prinsip ajaran Islam yang "rahmatan lil alamin" dan Islam yang bersifat inklusif. Salah seorang informan Y1 menjelaskan bahwa SMA Kemala

${ }^{28}$ Matthew B Miles, A. Michael Huberman, and Johnny Saldana, Qualitative Data Analysis: A Methods Sourcebook. Third Edition, The SAGE Handbook of Applied Social Research Methods, 2014. 
Bhayangkari 1 Surabaya berkomitmen untuk menguatkan sikap patriotisme siswa melalui pendidikan, termasuk Pendidikan Agama Islam, sehingga semua bentuk ekstrimisme dihindarkan dari sekolah ini.

Upaya itu dimaksudkan untuk menguatkan sikap patriotisme siswa di SMA Kemala Bhayangkari 1 Surabaya yang selama ini relatif baik. Sikap patriotisme siswa dapat dilihat pada sikap beragama mereka yang toleran terhadap sesama dan umat beragama lain. Mereka biasa melakukan kegiatan-kegiatan sekolah secara bersama-sama dan disiplin dalam bertingkah laku di lingkungan sekolah dan kehidupan sehari-hari. Para siswa SMA Kemala Bhayangkari 1 Surabaya sebagai generasi muda memiliki kecenderungan bersikap sebagaimana "gaya anak muda" pada umumnya, tetapi dalam wawasan persekolahan mereka merasa memiliki visi, misi dan cita-cita untuk memajukan negara Indonesia di kancah internasional. Misalnya, mereka memandang perlu mengenalkan dan mempromosikan budaya-budaya lokal dalam kancah global. Berkaitan dengan hal ini, Z2 mengatakan bahwa "melakukan upacara bendera secara tertib, memakai pakaian adat dalam even tertentu, dan mengunjungi museum untuk mempelajari sejarah perjuangan bangsa penting untuk membentuk karakter siswa."

Gambaran tentang sikap patriotisme siswa SMA Kemala Bhayangkari 1 Surabaya menurut pendapat Y2 tercermin dalam kegiatan-kegiatan yang mereka lakukan, terutama di lingkungan sekolah yang mendapat dukungan dari sekolah. Dia mengatakan bahwa “anak-anak sekolah ini memiliki jiwa patriotisme yang cukup baik dibuktikan mereka secara aktif ikut serta dalam kegiatan-kegiatan yang bersifat nasionalisme dan kebangsaan, seperti peringatan hari besar nasional dan perlombaan-perlombaan.” Atas dasar itu, dia berpendapat bahwa kondisi patriotisme siswa SMA Kemala Bhayangkari 1 Surabaya cukup baik, tapi dia juga mengakui adanya beberapa siswa yang masih memerlukan motivasi. Y2 menambahkan bahwa pernah ada kasus siswa yang terlibat dalam demonstrasi politik dan bolos sekolah, tetapi sekolah mengambil langkah melakukan pendataan dan pendampingan secara personal. Data itu menunjukkan bahwa siswa-siswi memiliki rasa kebangsaan dan sikap patriotisme yang cukup baik, meskipun masih ada siswa yang memerlukan dorongan dan bahkan pembinaan. Pembinaan sikap patriotisme menurut penelitian Agoes Dariyo memerlukan peran orang tua. ${ }^{29}$

${ }^{29}$ Agoes Dariyo, "Peran Pengasuhan Otoritatif Terhadap Patriotisme Remaja: Dengan Mediator Kepuasan Hidup Dan Nasionalisme," Jurnal Ketahanan Nasional 24, no. 3 (November 28, 2018): 326, https://doi.org/10.22146/jkn.38715.

Tribakti: Jurnal Pemikiran Keislaman

Volume 32, Nomor 1, Januari 2021 
Berkaitan dengan menjaga dan memperkuat sikap patriotisme dan kebangsaan peserta didik, pihak sekolah membuat kebijakan untuk memberikan kegiatan-kegiatan pembiasaan kepada siswa, di antaranya menyanyikan lagu wajib nasional sebelum pembelajaran dimulai, memakai pakaian adat, serta penekanan kedisiplinan siswa. Kegiatan pembiasaan positif ini menurut Y3 juga dilakukan dalam pembelajaran, misalnya “membaca do’a sebelum pelajaran dimulai, mendengarkan lagu-lagu nasional maupun daerah untuk menanamkan rasa cinta tanah air, dan dalam event peringatan hari besar nasional sekolah juga melibatkan siswa dalam berbagai kegiatan.”

Selain menggunakan pendekatan melalui pembiasaan, dewan guru Pendidikan Agama Islam juga melakukan pendampingan psikologis siswa. Beberapa siswa yang dinilai masih kurang memiliki sikap patriotisme dilakukan pendampingan secara berkala. Y2 menjelaskan bahwa "siswa yang kurang peduli terhadap kegiatan keagamaan dilakukan pembinaan melalui pendekatan shalat dan refleksi. Ini dilakukan agar hati mereka tersentuh, karena masih ada siswa yang perlu didorong agar lebih disiplin menjalankan shalat." Pendampingan siswa yang dinilai mengalami masalah dalam sikap patriotisme menggunakan pendekatan emosional dan spiritual dipandang sesuai dengan permasalahan. Seorang siswa yang mengalami permasalahan sikap patriotisme diberikan nasehat-nasehat dengan mengontekskan pada ajaran Islam. Guru Pendidikan Agama Islam menjelasan bahwa memiliki sikap patriotisme atau cinta tanah air merupakan bagian dari ajaran agama Islam. Selain itu, Y2 sebagai role model dalam proses pendampingan ini, juga menerapkan pendekatan-pendekatan spiritual, yakni dengan mengajak siswa yang bermasalah untuk melakukan ibadah, seperti shalat, berdoa, dan memahami nilai-nilai agama Islam.

Sikap Patriotisme berperan penting dalam kehidupan berbangsa dan bernegara, karena seseorang yang memiliki sikap patriotisme akan melahirkan mencintai dan menjaga persatuan bangsa, bahkan rela berkorban untuk kepentingan bangsa dan semangat perjuangan. ${ }^{30}$ Seorang individu atau kelompok sebagai bagian dari suatu bangsa wajib mencintai negaranya, dan rela berkorban demi kepentingan negaranya. Patriotisme adalah sikap cinta akan pencapaian kemajuan bangsanya, adanya keinginan untuk memelihara ciri-ciri bangsa dan budaya luhur bangsa. Ada beberapa nilai yang terkandung dalam sikap patriotisme, yaitu kesetian, keberanian, rela berkorban, serta

30 Wijayanto J. and Marzuki, "Pendidikan Bela Negara Sebagai Tonggak Peradaban Jiwa Patriotisme Generasi Muda.” 
kecintaan pada bangsa dan negara. Sikap patriotisme diartikan sebagai sikap untuk selalu mencintai atau membela tanah air, seorang pejuang sejati, pejuang bangsa yang mempunyai semangat, sikap dan perilaku cinta tanah air, dimana ia sudi mengorbankan segala-galanya bahkan jiwa sekalipun demi kemajuan, kejayaan dan kemakmuran tanah air. Dengan demikian, sikap patriotisme berarti sikap sebagai warga negara yang seutuhnya, berjuang untuk kemajuan bangsa, dan rela berkorban untuk kepentingan bangsa.

Patriotisme memiliki peranan penting dalam kehidupan berbangsa dan bernegara. Sikap cinta tanah air membangkitkan semangat perjuangan untuk menjaga kesatuan, dan kedaulatan negara, ${ }^{31}$ serta demi menjaga keutuhan, kerukunan dan kepentingan bersama serta membela bangsa dan negara. ${ }^{32}$ Seorang warga negara yang mampu menerapkan sikap patriotisme dengan baik, senantiasa mengutamakan kepentingan bersama di atas kepentingan pribadinya, merupakan sikap yang harus dilakukan oleh semua warga negara. Menjaga keharmonisan persatuan dan kesatuan, serta kerukunan antarwarga menjadi sebuah konsensus yang senantiasa memperoleh prioritas utama di atas kepentingan pribadi.

Di kalangan ahli tidak ada kesepakatan dalam merumuskan konsep negara, tetapi mereka bersepakat akan perlunya negara. ${ }^{33}$ Negara adalah suatu gejala sosial dan politik yang memiliki kekuasaan tertinggi untuk mengatur warga negaranya yang mendiami sebuah wilayah. Negara merupakan istitusi atau seperangkat institusi yang menyatukan penduduknya dalam suatu wilayah teritorial yang ditandai secara jelas dibawah otoritas tunggal untuk menjamin tercapainya tujuan kehidupan bersama, sehingga negara memiliki otoritas mengatur penduduknya untuk mencapai tujuan bersama. ${ }^{34}$ Karena itu, keberagaman dan perbedaan dalam kehidupan masyarakat yang sangat dinamis rentan akan perpecahan dan permusuhan, sehingga penanaman dan penguatan sikap patriotisme yang didasarkan pada kebersamaan sangat penting. Lunturnya nilai-nilai patriotisme dan semangat kebangsaan terjadi karena kurangnya pemahaman tentang hakikat hidup berbangsa dan bernegara. Munculnya berbagai macam problematika krisis patriotisme

${ }^{31}$ Rini Aristin, "Upaya Menumbuhkan Patriotisme Dan Nasionalisme Melalui Revitalisasi Makna Identitas Nasional Di Kalangan Generasi Muda," Jurnal Ilmiah Administrasi Negara, 2017.

${ }^{32}$ Suwarno Widodo, "Implementasi Bela Negara Untuk Mewujudkan Nasionalisme," Jurnal Ilmiah Civis, 2011.

${ }^{33}$ Usman, "Negara Dan Fungsinya," Al-Daulah, 2015.

34 Junaedi Junaedi and Agus Dimiyati, "Hakikat Dan Fungsi Negara: Telaah Atas Persoalan Kebangsaan Di Indonesia," Logika : Journal of Multidisciplinary Studies, 2020, https://doi.org/10.25134/logika.v11i01.2717.

Tribakti: Jurnal Pemikiran Keislaman Volume 32, Nomor 1, Januari 2021 
menjadi landasan pertimbangan untuk melaksanakan upaya penguatan bagi generasi bangsa. Dalam konteks pembelajaran di sekolah, sasaran utama upaya penguatan sikap patriotisme adalah siswa.

Menghadapi tren kehidupan modern di kalangan remaja, SMA Kemala Bhayangkari 1 Surabaya melaksanakan program penguatan sikap patriotisme di kalangan siswa menggunakan emosional dan spiritual berbasis Pendidikan Agama Islam. Pendidikan Agama Islam sebagai sebuah mata pelajaran menghadirkan materi-materi yang berkaitan dengan nilai-nilai agama dan kebangsan. Konsep integrasi antara nilai agama dan kebangsaan menjadi poin penting dalam pembelajaran Pendidikan Agama Islam. Penelitian di kalangan mahasiswa juga menunjukkan bahwa agama Islam berpengaruh secara signifikan terhadap penguatan sikap nasionalisme. Penelitian sejalan dengan kajian Abdul Hamid yang menunjukkan bahwa Pendidikan Agama Islam berperan menguatkan nasionalisme. ${ }^{35}$ Beberapa hasil penelitian itu memperkuat penelitian ini yang mengungkapkan penguatan sikap patriotisme berbasis Pendidikan Agama Islam di SMA Kemala Bhayangkari 1 Surabaya. Beberapa aspek mendasar yang perlu ditekankan adalah bahwa Islam adalah agama yang menganjurkan untuk mencintai bangsa yang bertujuan untuk memajukan rakyat dan segenap tumpah darah, Pendidikan Agama Islam harus dapat menyajikan sekaligus mengajarkan sejarah perjuangan bangsa yang faktanya memiliki kontribusi besar dalam memperjuangkan kemerdekaan Indonesia. ${ }^{36}$

Dalam implementasi penguatan sikap patriotisme berbasis PAI, guru memiliki peran penting dalam penyajian materi pelajaran untuk memotivasi siswa dan menanamkan nilai-nilai kebangsaan. Hasil penelitian ini sejalan dengan penelitian Irhadi Yamin yang mengungkapkan peran guru Pendidikan Agama Islam dalam menumbuhkan wawasan kebangsaan Melalui pembelajaran PAI guru menumbuhkan nilai-nilai wawasan kebangsaan, antara lain tentang tekad bersama untuk berkehidupan kebangsaan yang bebas, merdeka, dan bersatu. Guru juga menumbuhkan wawasan tentang cinta tanah air dan bangsa, sikap demokratis, dan kesetiakawanan sosial. Iksan Kamil Sahri dalam penelitiannya mengungkapkan cara yang dapat ditempuh guru dalam menanamkan

\footnotetext{
${ }^{35}$ Abdul Hamid, "Peranan Pendidikan Agama Islam Dalam Penguatan Nasionalisme Di Indonesia," Jurnal Pendidikan Agama Islam, 2018, https://doi.org/10.14421/jpai.2018.151-02.

36 Setiawan, "Islam Dan Nasionalisme: Pandangan Pembaru Pendidikan Islam Tentang Nasionalisme (Kasus Ahmad Dahlan Dan Abdul Wahab Khasbullah)." 
nasionalisme dengan cara mengintegrasikan nilai-nilai kearifan lokal dalam proses Pembelajaran Agama Islam di sekolah. ${ }^{37}$

Penguatan sikap patriotisme di SMA Kemala Bhayangkari 1 Surabaya dilakukan melalui beberapa program dan kegiatan yang didasarkan pada Pendidikan Agama Islam. Dalam pembelajaran PAI, guru memberikan nasehat dan motivasi kepada siswa di awal pembelajaran, dan memberikan penguatan terhadap respon siswa. Metode yang digunakan oleh guru untuk memberikan penguatan sikap patriotisme kepada siswa melalui ceramah dan diskusi. Ceramah merupakan metode klasik yang banyak digunakan dalam proses pembelajaran, termasuk dalam pembelajaran PAI. Meskipun ceramah dipandang sebagai metode klasik, namun penelitian menunjukkan bahwa dalam pembelajaran di kelas dengan menerapkan metode ceramah menunjukkan efektifitasnya dalam pengembangan kognitif, afektif maupun psikomotorik. ${ }^{38}$ Dalam pandangan secara umum, metode ceramah dalam pembelajaran PAI memang memiliki kelebihan dan kekurangan. ${ }^{39}$

Diskusi adalah suatu proses yang dua atau lebih individu yang berintegrasi secara verbal dan saling berhadapan muka mengenai tujuan dan sasaran yang sudah ditentukan melalui tukar menukar informasi, mempertahankan pendapat, ataupun memecahkan masalah. ${ }^{40}$ Metode diskusi digunakan sebagai tahapan pembelajaran untuk melatih kemampuan analisis peserta didik. Di dalam proses penguatan yang diterapkan, peserta didik disajikan materi-materi ataupun contoh kasus yang berkaitan dengan kurangnya sikap patriotisme. Penerapan metode dalam penguatan sikap patriotisme digunakan untuk memahami masalah-masalah sosial. Guru PAI menyajikan materi-materi dan contoh kasus yang berkaitan dengan persoalan sikap patriotisme, kemudian para siswa menganalisis kasus tersebut sesuai dengan arahan dan bimbingan guru. Melalui penerapan social problem meeting ini, para siswa mampu mempelajari dan bertingkah laku sesuai dengan kaidah-kaidah yang telah dipelajari dan ditentukan. Dengan kata lain, menggunakan model diskusi ini sebagai sebuah metode untuk penguatan sikap

\footnotetext{
${ }^{37}$ Iksan Kamil Sahri, "Penanaman Nasionalisme Melalui Kearifan Lokal Dalam Pendidikan Agama Islam Di Sekolah Dasar,” TARBAWI, 2017, https://doi.org/10.36781/tarbawi.v4i1.2915.

${ }^{38}$ Sari Narulita Raden Rizky Amaliah, Abdul Fadhil, "Penerapan Metode Ceramah Dan Diskusi Dalam Meningkatkan Hasil Belajar PAI Di SMA Negeri 44 Jakarta," Studi Al-Qur'an; Membangun Tradisi Berfikir Qur'an, 2014.

39 Syahraini Tambak, "Metode Ceramah: Konsep Dan Aplikasi Dalam Pembelajaran Pendidikan Agama Islam,” Jurnal Tarbiyah, 2014.

${ }^{40}$ Sahraini Tambak, "Metode Diskusi Dalam Pembelajaran Pendidikan Agama Islam," Al-Hikmah: Jurnal Agama Dan Ilmu Pengetahuan, 2015, https://doi.org/10.25299/jaip.2015.vol12(1).1444.
}

Tribakti: Jurnal Pemikiran Keislaman

Volume 32, Nomor 1, Januari 2021 
patriotisme siswa dipandang cukup sesuai. Penguatan sikap patriotisme dalam pembelajaran PAI dengan metode diskusi ini sejalan dengan penelitian Syahraini Tambak yang mengidentifikasi beberapa aspek penting dalam diskusi, yaitu pengembangan penguasaan bahan, tukar-menukar gagasan dan pendapat, bersifat humanis dan demiokratis, dan memecahkan suatu masalah secara bersama-sama. ${ }^{41}$ Penelitian Taufiq Ziaul Haq membuktikan bahwa metode diskusi efektif dalam pembelajaran Pendidikan Agama Islam, dan beragam seperti mengingkatan perestasi, meningkatkan interaksi sosial, meningkatkan keaktifan, dan meningkatkan kecerdasan emosional. ${ }^{42}$ Pada prinsipnya, siswa menyukai pembelajaran yang menyenangkan dan terlibat dalam pembelajaran.

Teori reinforcement Skinner menerangkan bahwa tahapan pertama yang harus dilaksanakan dalam proses penguatan adalah pemberian stimulus untuk memunculkan respon. Pada tahapan ini, seorang guru memberikan stimulus-stimulus untuk mengetahui respon awal dari siswa. Jika menganalisa data-data yang diperoleh selama penelitian, diketahui bahwa tahap pertama yang dilakukan oleh guru PAI untuk memberikan penguatan patriotisme kepada peserta didik ialah dengan melakukan kegiatan motivasi, berupa nasehat ataupun penyajian fakta-fakta sosial terkait pentingnya sikap patriotisme. Motivasi atau nasehat yang dilakukan bertujuan untuk membangkitkan semangat emosional peserta didik, dengan memberikan contoh kasus yang terjadi di lapangan, serta memberikan pemahaman-pemahaman baru yang bersifat open minded. Setelah siswa memberikan respon, seorang guru bertugas untuk memetakan dan mengelompokkan berbagai macam respon yang telah dimunculkan oleh siswa. Pengelompokkan ini sebagai penentu tahapan selanjutnya yang diberikan kepada siswa. Maka, dalam tahapan kedua ini, seorang guru harus memiliki kemampuan yang baik untuk mengamati proses kemajuan siswa selama tahap penguatan.

Selain itu, juga terdapat usaha pendampingan kepada siswa yang kurang memiliki respon positif setelah mendapatkan penguatan sikap patriotisme dari guru Pendidikan Agama Islam. Pendampingan ini dilakukan melalui pendekatan psikologis. Guru mengajak interaksi siswa yang bermasalah secara personal. Hal ini bertujuan untuk memahami secara langsung kondisi psikis dan emosional siswa. Selama program penguatan, guru Pendidikan Agama Islam mengacu pada indikator-indikator sikap

${ }^{41}$ Tambak.

42 Taufiq Ziaul Haq, "Metode Diskusi Pada Pembelajaran Pendidikan Agama Islam," TA'DIBUNA. Jurnal Pendidikan Agama Islam, 2019, https://doi.org/10.30659/jpai.2.2.15-24. 
patriotisme yang wajib dimiliki oleh siswa yaitu (1) cinta tanah air, (2) rela berkorban untuk kepentingan bangsa dan negara, (3) menempatkan persatuan dan kesatuan bangsa diatas kepentingan pribadi dan golongan, (4) berjiwa pembaharu, (5) tidak kenal menyerah dan putus asa. ${ }^{43}$ Indikator-indikator ini diupayakan dapat ditumbuhkan dan dikuatkan melalui pembelajaran PAI untuk menguatkan sikap patriotisme sisiwa.

Penguatan sikap patriotisme selain melalui pembelajaran PAI, juga dilakukan melalui pembiasaan. Beberapa penelitian menunjukkan bahwa pembiasaan baik merupakan stimulus yang akan menimbulkan respons positif. ${ }^{44}$ Program pembiasaan yang diterapkan di SMA Kemala Bhayangkari 1 Surabaya untuk menguatkan sikap patriotisme siswa antara lain menyanyikan lagu wajib nasional sebelum mata pelajaran dimulai, memakai pakaian adat dan penekanan kedisiplinan terhadap tata tertib. Siswa yang telah terbiasa dengan pembiasaan positif di sekolah, mereka mengalami peningkatan emosional, yakni merasa tergugah jati diri bangsanya, sehingga lebih semangat untuk belajar sekaligus menjaga keutuhan bangsa dan negaranya. Usaha ini terlihat dari sikap siswa yang mampu menunjukkan perubahan positif pasca program pembiasaan. Hal ini juga berkaitan dengan pembentukan lingkungan sekolah yang kondusif untuk menerapkan nilai-nilai kebangsaan. Penelitian Ginting \& Susanna mengungkapkan bahwa lingkungan sosial secara signifikan berpengaruh terhadap sikap nasionalisme siswa. ${ }^{45}$ Pendapat ini didukung oleh Riana Monalisa Tamara bahwa lingkungan masyarakat memiliki peran lebih tinggi dalam membentuk sikap kepedulian lingkungan siswa. ${ }^{46}$ Pemahaman tentang peran lingkungan yang sangat besar dalam pembentukan sikap seseorang, program penguatan sikap patriotisme berbasis Pendidikan Agama Islam berusaha untuk membentuk lingkungan yang mampu mendukung terbentuknya sikap patriotisme siswa.

Program pembiasaan dapat membentuk lingkungan yang mendorong siswa untuk beradaptasi dan terbiasa dalam sebuah kondisi yang telah ditentukan. Pembiasaan berfungsi membangkitkan psikologis siswa untuk bersikap sesuai dengan pembiasaan yang dikondisikan. Siswa yang sebelumnya belum terbiasa memiliki sikap patriotisme,

${ }^{43}$ Putra, "Perkembangan Jiwa Nasionalisasi Dan Patriotisme Era Reformasi Di Indonesia."

44 Tatan Zenal Mutakin, "Penerapan Teori Pembiasaan Dalam Pembentukan Karakter Religi Siswa Di Tingkat Sekolah Dasar,” Edutech, 2014, https://doi.org/10.17509/edutech.v13i3.3089.

452017 Ginting\&Susanna, "Pengaruh Lingkungan Sosial Terhadap Sikap Nasionalisme Siswa," Jurnal Ilmu Pendidikan Sosial, 2017.

46 Riana Monalisa Tamara, "Peranan Lingkungan Sosial Terhadap Pembentukan Sikap Peduli Lingkungan Peserta Didik Di Sma Negeri Kabupaten Cianjur," Jurnal Geografi Gea, 2016, https://doi.org/10.17509/gea.v16i1.3467.

Tribakti: Jurnal Pemikiran Keislaman

Volume 32, Nomor 1, Januari 2021 
dengan mengenal kebudayaan bangsa dan pembiasaan positif pada akhirnya bersemangat untuk mempelajari kebudayaan tersebut. Pembentukan lingkungan untuk pembiasaan positif diawali dengan penanaman kedisplinan melalui tata tertib sekolah yang berlaku pada seluruh warga sekolah. Semua warga sekolah wajib menaati tata tertib yang telah disepakati bersama, dan setiap pelanggaran terhadap tata tertib tersebut mendapatkan sanksi. Siswa juga dikenalkan dengan budaya lokal, misalnya melalui kegiatan memakai pakaian adat pada hari tertentu untuk menumbuhkan nilai-nilai kebangsaan. Penggabungan antara penguatan sikap patriotisme siswa melalui Pendidikan Agama Islam dan program pembiasaan ini ternyata dapat menguatkan sikap patriotisme pada siswa. Ada kecenderungan siswa yang telah mendapatkan program penguatan tersebut, memiliki sikap patriotisme yang lebih baik. Mereka cenderung semakin mencintai bangsa dan negaranya, budayanya, dan sekaligus bersikap toleransi terhadap sesama. Rasa persatuan dan kesatuan juga dikuatkan melalui berbagai kegiatan dengan melibatkan siswa.

Pendidikan Agama Islam memuat nilai-nilai kebangsaan yang bersumber pada ayat Al-qur'an. Al-quran sebagai kitab suci umat Islam terdapat ayat-ayat yang mengisyaratkan makna terkait dengan sikap patriotisme atau cinta tanah air. Di antara ayat Al-quran yang menjelaskan tentang kebangsaan terdapat dalam surat al-Hujurat, bahwa Allah menciptakan manusia terdiri dari laki-laki dan perempuan dan menjadikan manusia berbangsa-bangsa dan bersuku-suku agar saling kenal mengenal. ${ }^{47}$ Menurut Quraish Shihab dalam Tafsir Al-Misbah, ayat di atas berarti sebagai salah satu wujud penisbatan manusia terhadap tanah kelahirannya atau tanah air. Hal itu menunjukkan bahwa mereka telah memiliki rasa cinta terhadap tanah tumpah darahnya sejak lahir. ${ }^{48}$ Kajian Alifuddin Ihsan mengungkapkan bahwa Al-quran memuat ayat-ayat yang mengandung nilai-nilai cinta tanah air. ${ }^{49}$ Quraish Shihab dalam bukunya Wawasan Alquran menyatakan bahwa unsur-unsur nasionalisme dapat ditemukan dalam Al-quran: Persamaaan keturunan, persamaan sejarah, dan persamaan cinta tanah air. ${ }^{50}$

\footnotetext{
${ }^{47}$ Syofrianisda, "Nilai-Nilai Pendidikan Akhlak Dalam Perspektif Al-Qur'an,” Jurnal Al-Ta'dib, 2018.

${ }^{48}$ M. Quraish Shihab, Tafsir Al-Mishbah Pesan, Kesan Dan Keserasian Al-Qur'an, Jakarta: Lentera Hati, 2002.

${ }^{49}$ M. Alifudin Ikhsan, "Nilai - Nilai Cinta Tanah Air Dalam Perspektif Al-Qur'an,” Jurnal Ilmiah Pendidikan Pancasila Dan Kewarganegaraan, 2017, https://doi.org/10.17977/um019v2i22017p108.

${ }^{50}$ M. Quraish Shihab, "Wawasan Al-Qur'an Tafsir Maudhu'I Atas Pelbagai Persoalan Umat," Wawasan Al-Qur'an Tafsir Maudhu'I Atas Pelbagai Persoalan Umat, 1996. 
Berdasarkan beberapa kajian di atas, diketahui bahwa pada hakikatnya Islam menganjurkan umatnya untuk mencintai bangsa dan tanah airnya dengan baik. Pemenuhan hak dan kewajiban dalam kehidupan berbangsa dan bernegara merupakan kewajiban setiap warga negara. Bagi seorang muslim mengutamakan kepentingan bersama berada di atas kepentingan pribadinya, sehingga setiap muslim yang baik akan mencintai bangsa dan tanah airnya dengan baik. Dalam konteks Indonesia, sejarah mencatat bahwa dalam sejarah perjuangan kemerdekaan Indonesia, umat Islam tampil sebagai garda terdepan. Pandangan ini sejalan dengan ajaran Islam yang terkandung dalam Al-quran dan assunnah, dan termuat dalam Pendidikan Agama Islam.

\section{Kesimpulan}

Pendidikan Agama Islam di sekolah umum memuat isi pelajaran tentang karakter rela berkorban, mencintai bangsa dan negara, persatuan dan kesatuan yang merupakan karakteristik sikap patriotisme. Penguatan sikap patriotisme di SMA Kemala Bhayangkari 1 Surabaya yang dilakukan melalui pembelajaran PAI dan budaya sekolah menunjukkan hasil yang cukup baik. Implementasi penguatan sikap patriotisme dalam pembelajaran PAI dilakukan dengan mengorelasikan nilai-nilai ajaran Islam dalam PAI dengan aspek-aspek sikap patriotisme. Proses penanaman nilai-nilai itu dimulai dengan menjelaskan dan mengeksplorasi nilai-nilai patriotisme, kemudian dikaitkan dengan berbagai permasalahan dalam kehidupan masyarakat dan didiskusikan dengan siswa dengan model problem solving. Penguatan sikap patriotisme juga dilakukan budaya sekolah, baik melalui tata tertib sekolah, kegiatan-kegiatan sekolah dan pembiasaan.

Penerapan program dan model pembelajaran PAI berbasis kebangsaan lebih mengenalkan kepada siswa bahwa secara konseptual, ajaran Islam sejalan dengan nilainilai patriotisme. Selain itu, penelitian ini juga memberikan catatan kepada para pengembang kurikulum, bahwa PAI membutuhkan penyesuaian kurikulumn dan isi materi sebagai alternatif solusi terhadap krisis patriotisme dan kebangsaan yang sedang terjadi saat ini.

\section{Daftar Pustaka}

Amanda, Maudy Prihita, Sahadi Humaedi, and Meilanny Budiarti Santoso. "Penyalahgunaan Narkoba di Kalangan Remaja (Adolescent Subtance Abuse)." Prosiding Penelitian Dan Pengabdian Kepada Masyarakat, 2017. https://doi.org/10.24198/jppm.v4i2.14392.

Amin, Nasihun. "Menyemai Nasionalisme Dari Spirit Agama: Upaya Meredam Tribakti: Jurnal Pemikiran Keislaman Volume 32, Nomor 1, Januari 2021 
Radikalisme Beragama.” Jurnal Theologia, 2012.

Aprilia, Nuri, and Herdina Indrijati. "Hubungan Antara Kecerdasan Emosi Dengan Perilaku Tawuran Pada Remaja Laki-Laki Yang Pernah Terlibat Tawuran Di SMK 'B' Jakarta.' Jurnal Psikologi Pendidikan Dan Perkembangan, 2014.

Aristin, Rini. “Upaya Menumbuhkan Patriotisme Dan Nasionalisme Melalui Revitalisasi Makna Identitas Nasional Di Kalangan Generasi Muda.” Jurnal Ilmiah Administrasi Negara, 2017.

Azman, Azman. "Nasionalisme dalam Islam.” Al Daulah : Jurnal Hukum Pidana Dan Ketatanegaraan, 2017. https://doi.org/10.24252/ad.v6i2.4881.

Badan Narkotika Nasional Republik Indonesia. "Indonesia Drugs Report 2019." Pusat Penelitian Dan Informasi Badan Narkotika Nasional Republik Indonesia (Puslidatin BNN), 2019.

Basri, A. Said Hasan. "Fenomena Tawuran Antar Pelajar dan Intervensinya." Hisbah: Jurnal Bimbingan Konseling Dan Dakwah Islam, 2016. https://doi.org/10.14421/hisbah.2015.121-06.

Cohen, Louis, Lawrence Manion, and Keith Morrison. Research Methods in Education. Research Methods in Education, 2017. https://doi.org/10.4324/9781315456539.

Dariyo, Agoes. "Peran Pengasuhan Otoritatif Terhadap Patriotisme Remaja: Dengan Mediator Kepuasan Hidup Dan Nasionalisme." Jurnal Ketahanan Nasional 24, no. 3 (November 28, 2018): 326. https://doi.org/10.22146/jkn.38715.

Gill Profesor, Sarjit S, Madya Jabatan, Sains Kemasyaratan, Dan Pembangunan, Fakulti Ekologi Manusia, Calon Doktor, Falsafah Jabatan, et al. "Kesedaran Patriotik Dalam Kalangan Belia Bandar Di Semenanjung Malaysia Mohd Rahimi Ramli." Jurnal Sosial Ilmu Politik Universitas Hasanuddin, 2015.

Ginting\&Susanna, 2017. "Pengaruh Lingkungan Sosial Terhadap Sikap Nasionalisme Siswa.” Jurnal Ilmu Pendidikan Sosial, 2017.

Hamid, Abdul. "Peranan Pendidikan Agama Islam dalam Penguatan Nasionalisme di Indonesia." Jurnal Pendidikan Agama Islam, 2018. https://doi.org/10.14421/jpai.2018.151-02.

Haq, Taufiq Ziaul. "Metode Diskusi pada Pembelajaran Pendidikan Agama Islam." TA'DIBUNA: Jurnal Pendidikan Agama Islam, 2019. https://doi.org/10.30659/jpai.2.2.15-24.

Hayat, Heni. "Komunikasi Kekerasan Penyebab Tindak Kekerasan pada Tawuran" Journal Acta Diurna, 2019. https://doi.org/10.20884/1.actadiurna.2019.15.1.1579.

Ifrani, Ifrani. "Tindak Pidana Korupsi Sebagai Kejahatan Luar Biasa.” Al Adl : Jurnal Hukum, 2017.

Ikhsan, M. Alifudin. "Nilai-Nilai dan Cinta Tanah Air dalam Perspektif Al Quran" Jurnal Ilmiah Pendidikan Pancasila Dan Kewarganegaraan, 2017. https://doi.org/10.17977/um019v2i22017p108.

Junaedi, Junaedi, and Agus Dimiyati. "Hakikat dan Fungsi Negara: Telaah Atas Persoalan Kebangsaan di Indonesia." Logika : Journal of Multidisciplinary Studies, 2020. 
https://doi.org/10.25134/logika.v11i01.2717.

Malihah, Elly, Bunyamin Maftuh, and Rizki Amalia. "Tawuran Pelajar: Solidarity in the Student Group and Its Influence on Brawl Behaviour." Komunitas : International Journal of Indonesian Society and Culture. 2015. https://doi.org/10.15294/komunitas.v6i2.3301.

M. Husin Affan, Hafid Maksum. "Membangun Kembali Sikap Nasionalisme Bangsa Indonesia dalam Menangkal Budaya Asing di Era Globalisasi." Jurnal Pesona Dasar, 2016.

Miles, Matthew B, A. Michael Huberman, and Johnny Saldana. Qualitative Data Analysis: A Methods Sourcebook. Third Edition. The SAGE Handbook of Applied Social Research Methods, 2014.

Mursidin, Mursidin. "Pendidikan Agama Islam Berbasis Nasionalisme." Ta'dib: Jurnal Pendidikan Islam, 2019. https://doi.org/10.29313/tjpi.v8i1.4515.

Mutakin, Tatan Zenal. "Penerapan Teori Pembiasaan dalam Pembentukan Karakter Religi Siswa di Tingkat Sekolah Dasar." EDUTECH, 2014. https://doi.org/10.17509/edutech.v13i3.3089.

Nasution, Robby Darwis. "Pengaruh Modernisasi Dan Globalisasi Terhadap Perubahan Sosial Budaya Di Indonesia.” Jurnal Kominfo, 2017.

Prasetyo, Arif Rahman. "Implementasi Kebijakan Pendidikan Karakter Di Madrasah Tsanawiyah Muhammadiyah Al Manar Kabupaten Demak." Tribakti: Jurnal Pemikiran Keislaman, 2020. https://doi.org/10.33367/tribakti.v31i1.978.

Putra, Y S. "Perkembangan Jiwa Nasionalisme dan Patriotisme di Era Reformasi Indonesia.” Jurnal Dosen Universitas PGRI, 2017.

Raden Rizky Amaliah, Abdul Fadhil, Sari Narulita. "Penerapan Metode Ceramah Dan Diskusi Dalam Meningkatkan Hasil Belajar PAI Di SMA Negeri 44 Jakarta.” Studi Al-Qur'an; Membangun Tradisi Berfikir Qur'an, 2014.

Sahri, Iksan Kamil. "Penanaman Nasionalisme Melalui Kearifan Lokal Dalam Pendidikan Agama Islam Di Sekolah Dasar.” TARBAWI, 2017. https://doi.org/10.36781/tarbawi.v4i1.2915.

Setiawan, Daryanto. "Dampak Perkembangan Teknologi Informasi Dan Komunikasi Terhadap Budaya." JURNAL SIMBOLIKA: Research and Learning in Communication Study, 2018. https://doi.org/10.31289/simbollika.v4i1.1474.

Setiawan, Iwan. "Islam Dan Nasionalisme: Pandangan Pembaru Pendidikan Islam Tentang Nasionalisme (Kasus Ahmad Dahlan Dan Abdul Wahab Khasbullah)." Equilibrium: Jurnal Pendidikan, 2018. https://doi.org/10.26618/equilibrium.v5i2.1046.

Setyawan, Iwan, and Sri Sulistyawati. "Mewaspadai Bahaya Penyalahgunaan Narkotika Pada Kalangan Masyarakat Desa Bandar Khalifah Kecamatan Percut Sei Tuan Kabupaten Deli Serdang." In Prosiding Seminar Nasional Hasil Pengabdian 2019, 2019.

Shihab, M. Quraish. TAFSIR AL-MISHBAH Pesan, Kesan Dan Keserasian Al-Qur'an. Jakarta: Lentera Hati, 2002.

Tribakti: Jurnal Pemikiran Keislaman

Volume 32, Nomor 1, Januari 2021 
_. "Wawasan Al-Qur'an Tafsir Maudhu'I Atas Pelbagai Persoalan Umat." Wawasan Al-Qur'an Tafsir Maudhu'I Atas Pelbagai Persoalan Umat, 1996.

Subaryana. "Builing the Positive Self-Concept through Patriotism." Jurnal Dinamika Pendidikan Dasar, 2016.

Sugiman, Ainun Muchlisatun Rati. "Penanaman Nilai-Nilai Nasionalisme dan Patriotisme Melalui Materi Sikap Semangat Kebangsaan dan Patriotisme dalam Kehidupan Masyarakat Berbangsa dan Bernegara Pada Pembelajaran PKn DI SMAN 1 PUNDONG.” Academy of Education Journal 8, no. 2 (July 1, 2017): 17499. https://doi.org/10.47200/aoej.v8i2.370.

Suherry, Suherry. "Politik Pemberantasan Korupsi Di Indonesia.” Otoritas : Jurnal Ilmu Pemerintahan, 2017. https://doi.org/10.26618/ojip.v7i1.417.

Susilo, Sigit Vebrianto. "Refleksi Nilai-Nilai Pendidikan Ki Hadjar Dewantara Dalam Upaya-Upaya Pengembalian Jati Diri Pendidikan Indonesia." Jurnal Cakrawala Pendas, 2018. https://doi.org/10.31949/jcp.v4i1.710.

Syam, Hamdani M. "Globalisasi Media Dan Penyerapan Budaya Asing, Analisis Pada Pengaruh Budaya Populerkorea Di Kalangan Remaja Kota Banda Aceh." Avant Garde, 2015. https://doi.org/10.36080/AVG.V3I1.19.

Syofrianisda. "Nilai-Nilai Pendidikan Akhlak Dalam Perspektif Al-Qur'an.” Jurnal AlTa'dib, 2018.

Tamara, Riana Monalisa. "Peranan Lingkungan Sosial Terhadap Pembentukan Sikap Peduli Lingkungan Peserta Didik di SMA Negeri Kabupaten Cianjur." Jurnal Geografi Gea, 2016. https://doi.org/10.17509/gea.v16i1.3467.

Tambak, Sahraini. "Metode Diskusi Dalam Pembelajaran Pendidikan Agama Islam.” AlHikmah: Jurnal Agama Dan Ilmu Pengetahuan, 2015. https://doi.org/10.25299/jaip.2015.vol12(1).1444.

Tambak, Syahraini. "Metode Ceramah : Konsep dan Aplikasi dalam Pembelajaran Pendidikan Agama Islam.” JURNAL TARBIYAH, 2014.

Usman. "Negara Dan Fungsinya." Al-Daulah, 2015.

Widodo, Suwarno. "Implementasi Bela Negara Untuk Mewujudkan Nasionalisme." Jurnal Ilmiah Civis, 2011.

Wijayanto J., Rahmat, and Marzuki Marzuki. "Pendidikan Bela Negara Sebagai Tonggak Peradaban Jiwa Patriotisme di Indonesia." Jurnal Ilmiah Pendidikan Pancasila Dan Kewarganegaraan 3, no. 2 (December 26, 2018): 186. https://doi.org/10.17977/um019v3i2p186-191. 